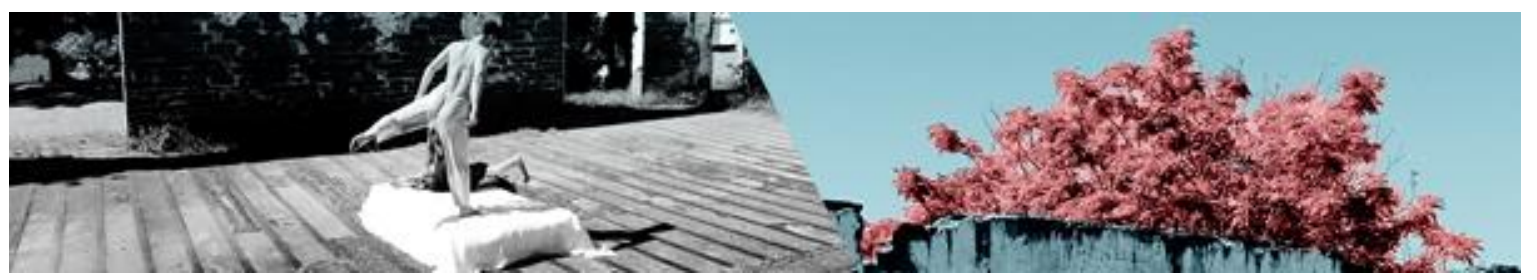

\title{
BAILA CASSINO GRUPO DE DANÇA E PROJETO DE EXTENSÃO BAILAR: NÚCLEO DE DANÇA NA MATURIDADE COMO PROPOSTA DE DESENVOLVIMENTO E PRODUÇÃO ARTÍSTICO-CULTURAL
}

\author{
Daniela Llopart Castro1 \\ Carmen Anita Hoffmann2 \\ Eleonora Campos da Motta Santos3
}

\begin{abstract}
Resumo: O texto é um relato das principais propostas do Baila Cassino, grupo de dança que integra o Projeto de Extensão Bailar: Núcleo de Dança na Maturidade da UFPel, apontando reflexões sobre os objetivos do projeto e resultados das ações realizadas. Buscou-se aporte teórico em Garcês et.al (2012), Vieira (12016), Strazzacappa (2012) e Rodrigues (2005-2006), dentre outros. Constatamos que o projeto conta com motivos para sua manutenção e continuidade, por afirmar sua relevância extensionista quando aproxima a comunidade ao ambiente universitário, desdobrando-se em ações disparadoras e orientadoras para grupos de maturidade, a exemplo do Baila Cassino que há 10 anos vem construindo uma trajetória de sucesso, através da dança.
\end{abstract}

Palavras- chave: Dança; Maturidade; Extensão universitária.

\section{BAILA CASINO DANCE GROUP AND DANCE EXTENSION PROJECT: DANCE MATURITY CENTER AS A PROPOSAL FOR ARTISTIC-CULTURAL DEVELOPMENT AND PRODUCTION}

\begin{abstract}
The text is an account of the main proposals of Baila Cassino, a dance group that integrates the Extension Project of the Dance Degree of UFPel - Bailar: Dance in Maturity Center, pointing out reflections on the project objectives and results of the actions carried out. A theoretical contribution was sought in Garcês et.al (2012), Vieira (12016), Strazzacappa (2012) and Rodrigues (2005-2006), among others. We verified that the project has reasons for its maintenance and continuity, for affirming its extensionist relevance when it brings the community closer to the university environment, unfolding in triggering and guiding actions for maturity groups, such as Baila Cassino, that during 10 years has been achieving a successful trajectory through dance.
\end{abstract}

Keywords: Dance; Maturity; University extension.

\footnotetext{
1 Professora Adjunta do Curso de Dança do Centro de Artes - UFPel. Mestre em Ciências do Movimento Humano. Doutoranda em Motricidade Humana - Dança (Universidade de Lisboa). Diretora Artística do Grupo Baila Cassino. Coordenadora do Projeto de Extensão Bailar: Núcleo de Dança na Maturidade/ UFPel (2012-2016). Coordenadora Geral dos I, II, III, IV, V e VI Cassino em Dança: Encontro Regional de Dança na Maturidade (2009-2015).

2 Professora Adjunta do Curso de Licenciatura em Dança e Professora do Programa de PósGraduação em Artes Visuais no Centro de Artes - UFPel. Doutora em História pela Pontifícia Universidade Católica do Rio Grande do Sul (PUC-RS). Coordenadora da Câmara de Extensão do Centro de Artes e Coordenadora do Projeto de Extensão Bailar: Núcleo de Dança na Maturidade. Colíder do Grupo de Pesquisa OMEGA - Observatório de Memória, Educação, Gênero e Arte (UFPel/CNPq).

3 Professora Adjunta do Curso de Licenciatura em Dança e Membro Externo do Programa de PósGraduação em Artes Visuais no Centro de Artes - UFPel. Doutora em Artes Cênicas e Mestre em Dança pela Universidade Federal da Bahia (UFBA). Chefe do Núcleo de Articulação de Coordenadores da Coordenação de Pedagogia Universitária da Pró-Reitoria de Ensino da UFPel.
}

CASTRO, Daniela Llopart; HOFFMANN, Carmen Anita; SANTOS, Eleonora Campos da Motta. Baila Cassino Grupo de Dança e Projeto de Extensão Bailar: Núcleo de Dança na Maturidade como proposta de desenvolvimento e produção artístico-cultural. Revista da FUNDARTE, Montenegro, p.33-52, ano 19, no 37, Janeiro/Março.

Disponível em: http://.seer.fundarte.rs.gov.br/index.php/RevistadaFundarte/index> 30 de março de 2019. 


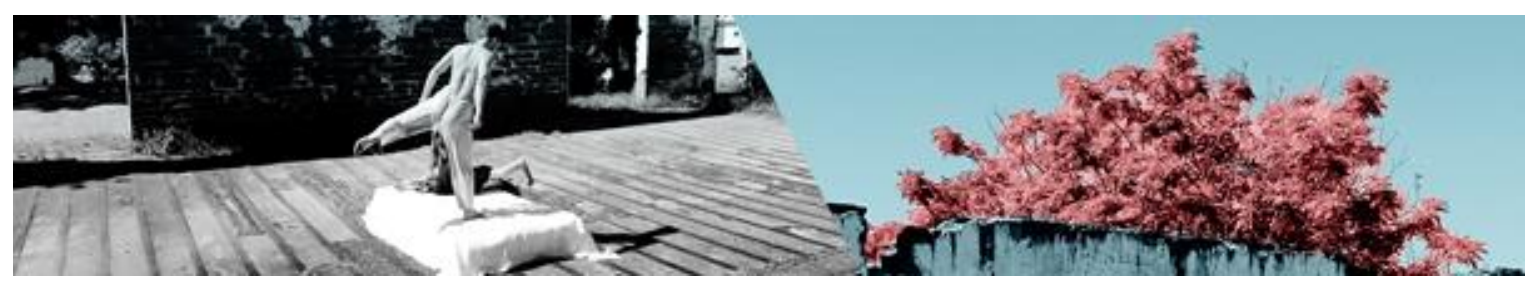

\section{Introdução}

Os avanços da ciência nas mais variadas áreas médicas, ocorridos nas últimas décadas, provocaram um aumento não só na expectativa, como também na qualidade de vida do ser humano. Nesse contexto o processo de envelhecimento no Brasil está se desenvolvendo a passos largos, o que faz emergir uma nova questão social: o aumento da quantidade de pessoas que atingem idades superiores aos 60 anos, com capacidade produtiva física e intelectual - um envelhecimento que exige atenção e alternativas de qualidade nos serviços de atendimento, em especial com relação à saúde e ao lazer. Entendemos, portanto, que a terceira idade deve ser vista como uma fase da vida com expectativas e oportunidades que precisam ser conquistadas a cada dia, já que a expectativa de vida está aumentando cada vez mais, alcançando no Rio Grande do Sul uma média de 75 anos, segundo os últimos dados do IBGE (FIGUEIREDO, 2016).

De acordo com Garcês et al., (2012), ao invés de o envelhecimento ser, como antigamente, um tempo de declínio e decréscimo das capacidades, sem condições de desenvolvimento humano, hoje, ao contrário, buscamos entender esse período como um momento em que as pessoas deixam a vida produtiva do mundo capitalista, mas não deixam de se desenvolver, seja de forma cultural, política, religiosa ou hedônica.

Por isso, atualmente o ciclo do envelhecimento é o momento de dedicar-se aos projetos que anteriormente foram adiados por falta de tempo para sua execução. Para se compreender o processo de envelhecimento, temos que investir na interdisciplinaridade através da educação permanente voltada aos princípios e à valorização do humano e do sensível.

Fazer parte de um grupo de convivência, praticar dança, viajar, se envolver na criação, engajar-se em atividades propostas coletiva e sistematicamente, provocam um sentimento de pertencimento e protagonismo nas produções artístico-culturais. Segundo Vieira (2016, p.165), "o corpo maduro quando dança afirma a vida desses dançantes". Assim surgiu o Baila Cassino (Figura 1), um grupo de dança composto por mulheres com mais de 50 anos de idade, que hoje integra o Projeto de Extensão Bailar: Núcleo de Dança na Maturidade.

CASTRO, Daniela Llopart; HOFFMANN, Carmen Anita; SANTOS, Eleonora Campos da Motta. Baila Cassino Grupo de Dança e Projeto de Extensão Bailar: Núcleo de Dança na Maturidade como proposta de desenvolvimento e produção artístico-cultural. Revista da FUNDARTE, Montenegro, p.33-52, ano 19, no 37, Janeiro/Março.

Disponível em: http://.seer.fundarte.rs.gov.br/index.php/RevistadaFundarte/index> 30 de março de 2019. 

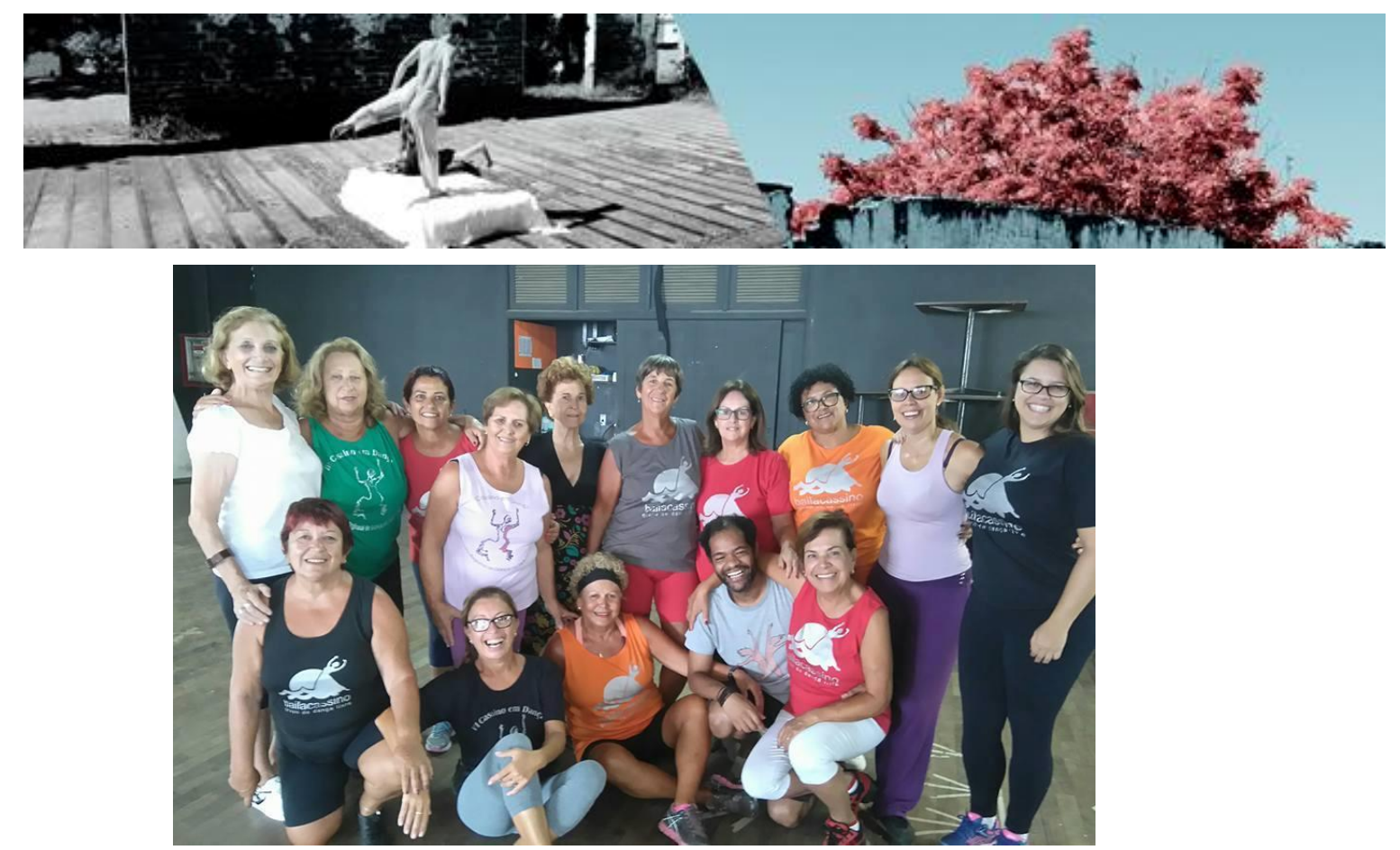

Figura 1: Aula de dança moderna, 2016. Foto: Acervo do Baila Cassino

Este projeto tem como objetivos principais proporcionar aos alunos de graduação em artes cênicas, bem como ao grupo Baila Cassino, a vivência em processos de composição coreográfica e montagem de espetáculos, difundindo a arte da Dança na Maturidade. Além de permitir à comunidade o acesso às informações difundidas no meio acadêmico em relação à produção em arte, através do aporte dos alunos como participantes desses processos. Busca, também, propiciar o intercâmbio de informações sobre o processo criativo entre comunidade e universidade, reforçando a formação acadêmica dos alunos de graduação, por meio da interligação de ações de ensino e pesquisa via extensão.

Através da exposição das ações e atividades do Bailar junto ao Grupo Baila Cassino, salientamos a relevância da extensão universitária no que tange à aproximação da comunidade com as ações acadêmicas e a importância do diálogo entre teoria e prática na construção dos saberes. Conforme Rodrigues (2005-2006), a extensão universitária, como uma práxis, tem o intuito de construir uma efetiva relação com a sociedade pautada no pensamento crítico. E assim acontece de fato com o trabalho que o Projeto Bailar vem desenvolvendo ao longo de seus cinco anos de atuação na Universidade Federal de Pelotas, tendo como parceiro o Grupo de Dança Baila Cassino.

\section{O Baila Cassino e a extensão da UFPel: caminhos e encontros}

O Baila Cassino é um grupo de dança formado por mulheres que decidiram

CASTRO, Daniela Llopart; HOFFMANN, Carmen Anita; SANTOS, Eleonora Campos da Motta. Baila Cassino Grupo de Dança e Projeto de Extensão Bailar: Núcleo de Dança na Maturidade como proposta de desenvolvimento e produção artístico-cultural. Revista da FUNDARTE, Montenegro, p.33-52, ano 19, no 37, Janeiro/Março.

Disponível em: http://.seer.fundarte.rs.gov.br/index.php/RevistadaFundarte/index> 30 de março de 2019. 


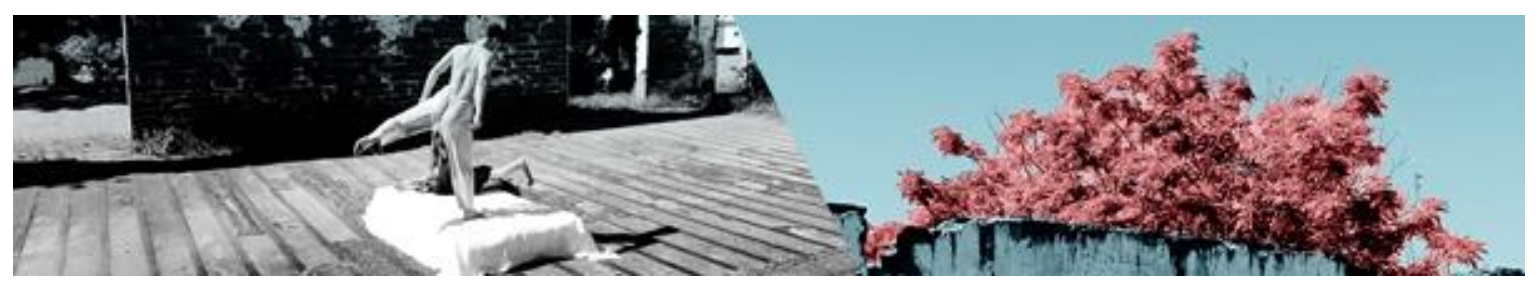

se dedicar à dança como forma de superação, motivação, autoestima e também almejando sensibilizar pessoas de diferentes classes sociais. O grupo trabalha com a dança a partir de diferentes gêneros, desbloqueando medos e vergonhas que vão se instaurando ao longo da vida, aliando os interesses das alunas com atividades que proporcionem seu desenvolvimento artístico, sempre com um olhar voltado para um trabalho onde todas se sintam produtoras de cultura e de arte.

Seguindo as estimativas, o trabalho de dança com a maturidade vem crescendo no mundo, e a intenção do Baila Cassino é mostrar que pessoas com esta faixa etária também devem fazer parte da produção de nossa cultura, principalmente pelo fato de carregarem uma grande bagagem histórica através de suas experiências de vida. Dessa forma, trazem de volta a ideia ancestral de respeito aos mais velhos como valorização de seu conhecimento. Não com o propósito de seguir sempre igual, mas sim através da troca de informações, criar novas propostas envolvendo ambas as gerações. Assim, não é apenas o artistabailarino jovem que pode ser profissional, já que possui condições físicas para isso, mas também o artista-bailarino idoso tem muito a contribuir com a dança, podendo tornar-se esteticamente interessante se trabalhado com este objetivo. Vieira (2016, p.170) reforça esta ideia através da seguinte afirmação:

[...] a dança na maturidade valoriza as qualidades pessoais de cada artista, o virtuosismo técnico dá lugar ao trabalho do corpo como um todo e este é reinventado a cada movimento poético que é ético e estético. Esse corpo amadurecido por via da idade procura outra forma de dançar em que está presente o repouso e a lentidão.

Sobre esses pilares filosóficos é que o Grupo Baila Cassino foi criado em 2007 e segue seu curso no caminho das artes cênicas. Ao longo destes 10 anos já participou de inúmeras atividades, tais como eventos culturais, festivais de dança, cursos variados, espetáculos artísticos, chás beneficentes, etc. Pela excelência de sua arte recebeu várias premiações dentro de sua faixa etária. Dessa forma, concordando com Strazzacappa (2012) sobre o papel da dança, salientamos seu propósito enquanto forma de arte e expressão, isto é, proporcionar ao corpo que dança possibilidades diferenciadas de percepção e cognição.

CASTRO, Daniela Llopart; HOFFMANN, Carmen Anita; SANTOS, Eleonora Campos da Motta. Baila Cassino Grupo de Dança e Projeto de Extensão Bailar: Núcleo de Dança na Maturidade como proposta de desenvolvimento e produção artístico-cultural. Revista da FUNDARTE, Montenegro, p.33-52, ano 19, no 37, Janeiro/Março.

Disponível em: http://.seer.fundarte.rs.gov.br/index.php/RevistadaFundarte/index> 30 de março de 2019. 


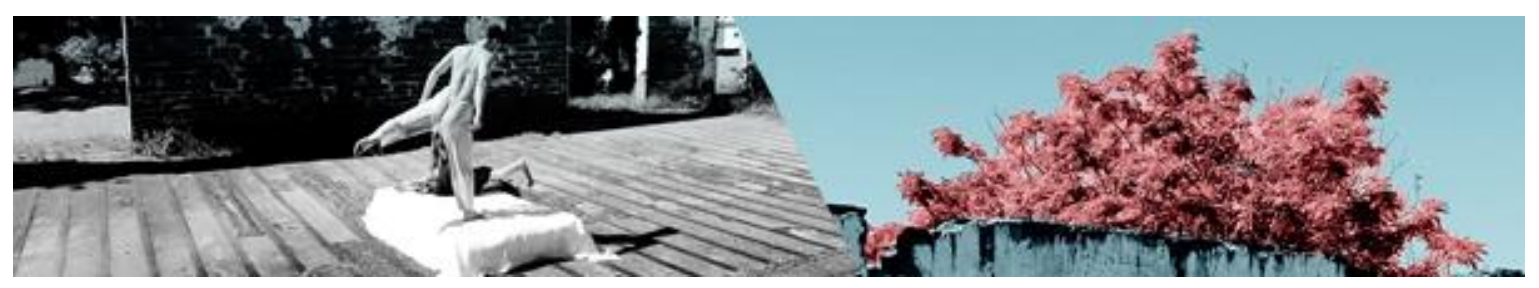

Em 2011 o grupo realizou a Turnê Salão Paraíso que percorreu cinco cidades do sul gaúcho. Foram elas: Arroio Grande, Jaguarão, Santa Vitória do Palmar, São José do Norte e Porto Alegre. O projeto foi patrocinado pelo Ministério da Cultura, Instituto Empreender e Petrobrás. Além dessas atividades, o grupo organizou seis edições do Cassino em Dança: Encontro Regional de Dança na Maturidade (Figura 2). Um evento que trouxe diversos grupos de diferentes localidades do Rio Grande do Sul, com uma proposta de integrar os participantes através de atividades variadas, preparadas especificamente para esta faixa etária.

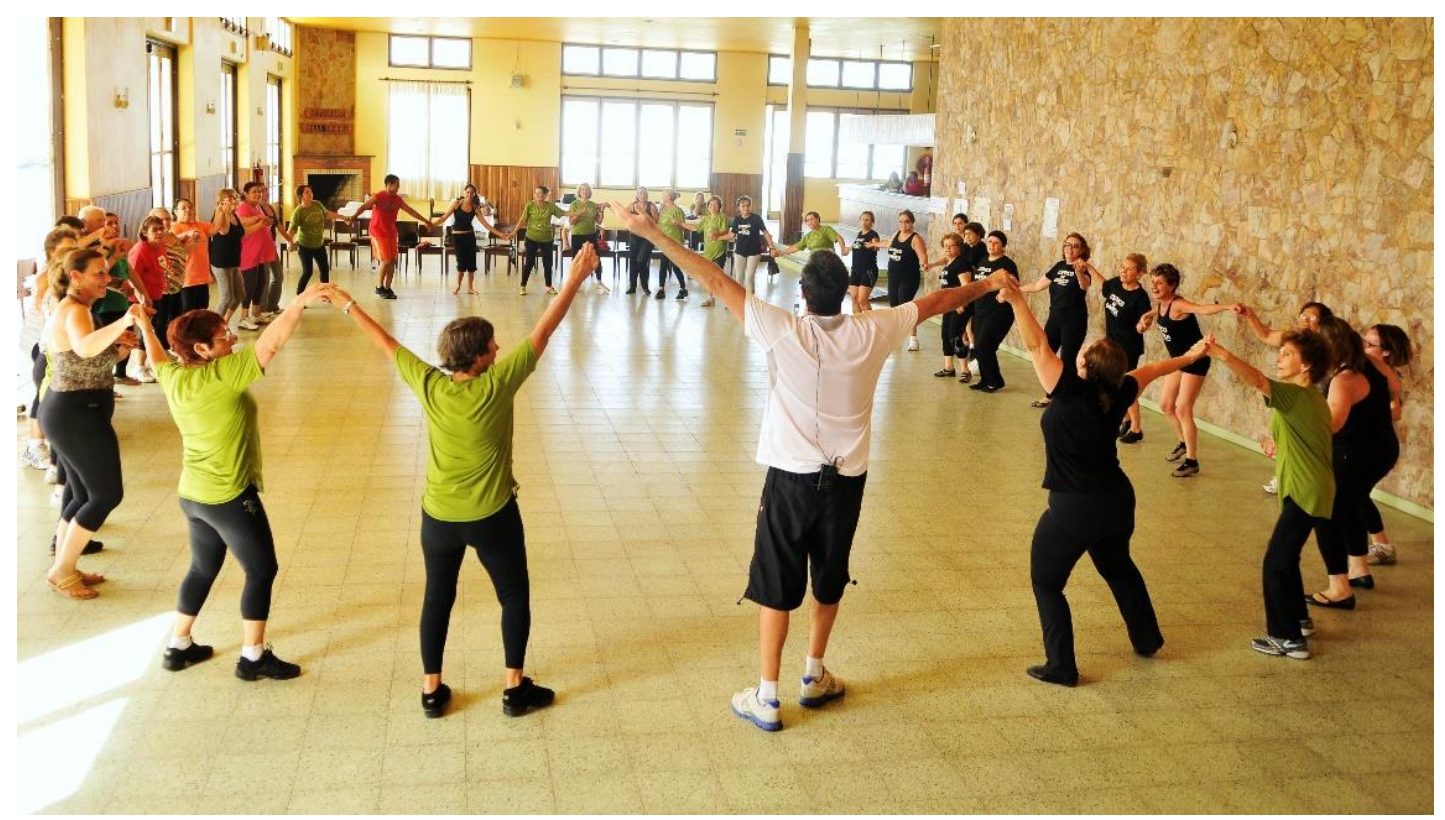

Figura 2: Oficina no III Cassino em Dança, 2011. Foto: Acervo do Baila Cassino

A intenção do grupo com as apresentações artísticas e demais atividades desenvolvidas, até os dias de hoje, é provocar reflexões sobre a vida moderna. Conforme Castro (2017, p.42):

A dança enquanto arte da contemporaneidade permite compreender 0 mundo de outra maneira. Através dos movimentos realizados, das concepções coreográficas, dos espetáculos articulados com elementos que o compõem, vai-se questionando a sociedade atual, e assim provocando outros olhares ao hibridismo da corporeidade que se apresenta no século $\mathrm{XXI}$.

CASTRO, Daniela Llopart; HOFFMANN, Carmen Anita; SANTOS, Eleonora Campos da Motta. Baila Cassino Grupo de Dança e Projeto de Extensão Bailar: Núcleo de Dança na Maturidade como proposta de desenvolvimento e produção artístico-cultural. Revista da FUNDARTE, Montenegro, p.33-52, ano 19, no 37, Janeiro/Março.

Disponível em: http://.seer.fundarte.rs.gov.br/index.php/RevistadaFundarte/index> 30 de março de 2019. 


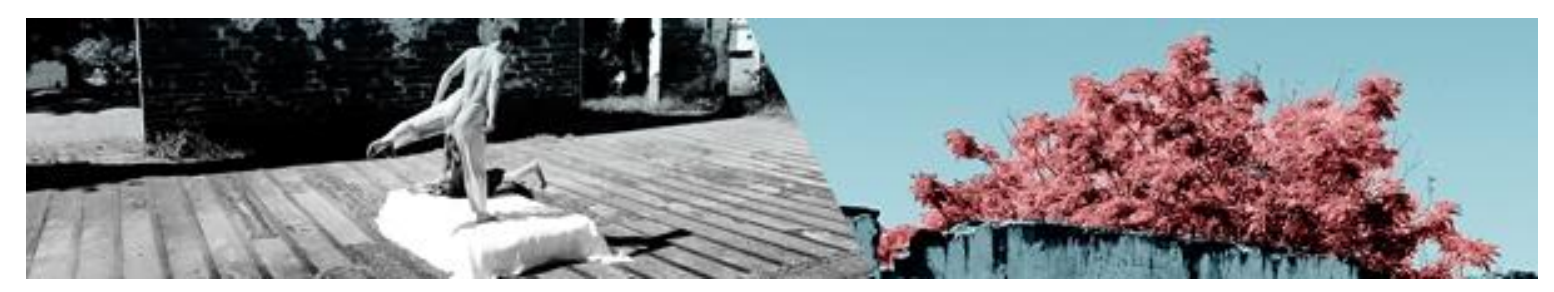

Em 2017 o Grupo Baila Cassino comemorou 10 anos de atividades ininterruptas. Suas relações com a comunidade em geral e com o meio acadêmico e artístico proporcionaram, ao longo deste tempo, experiências muito ricas para a vida das integrantes do grupo. Aprendizados como a responsabilidade com o trabalho, as relações de companheirismo e a apuração da fruição em arte, transformaram positivamente essas mulheres, empoderando-as como agentes ativas no século $\mathrm{XXI}$.

Ao legitimar o trabalho extensionista como participante ativo no processo de crescimento do grupo, concordamos com Rodrigues (2005-2006, p.85) quando afirma:

Para que a extensão universitária possa ser construída efetivamente é preciso que a comunidade reconheça a Universidade como um dos espaços para o exercício do pensamento crítico da sociedade, devendo, para tanto, adentrar ao seu interior, de modo a estabelecer um processo de diálogo permanente entre ambas.

A partir deste diálogo surge a construção do trabalho dentro do projeto Bailar. A proposta de dança desenvolvida com o Baila Cassino tem um cuidadoso olhar individual para cada integrante, respeitando seus limites e experiências. Nas criações, as ideias buscam aproveitar aspectos subjetivos das bailarinas como sensações, percepções, memórias e intuições na relação com o tema que estiver em questão. Essas vivências revelam o potencial artístico de cada uma (Figura 3). Projetos como este denotam o quanto a dança permite possibilidades infinitas, com qualquer que seja a realidade do indivíduo, colaborando, assim, com a mudança de paradigma em relação aos corpos dançantes no mundo em que vivemos.

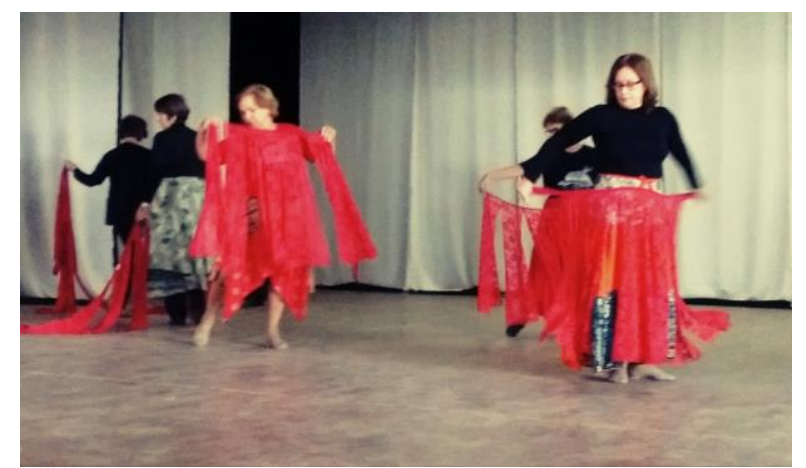

Figura 3: Ensaio do espetáculo Apenas Mulher, 2015. Foto: Arquivo Baila Cassino

CASTRO, Daniela Llopart; HOFFMANN, Carmen Anita; SANTOS, Eleonora Campos da Motta. Baila Cassino Grupo de Dança e Projeto de Extensão Bailar: Núcleo de Dança na Maturidade como proposta de desenvolvimento e produção artístico-cultural. Revista da FUNDARTE, Montenegro, p.33-52, ano 19, no 37, Janeiro/Março.

Disponível em: http://.seer.fundarte.rs.gov.br/index.php/RevistadaFundarte/index> 30 de março de 2019. 


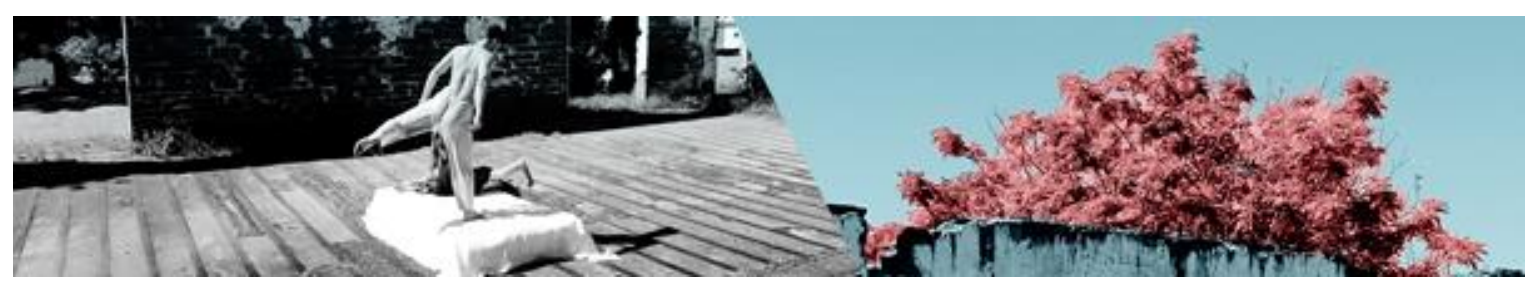

Ao todo foram criadas seis obras completas que serão apresentadas no decorrer deste texto. Essas obras configuram-se como espetáculos de dança e foram desenvolvidas ao longo dos dez anos de atuação do grupo. Todas tiveram sua estreia na Sociedade Amigos do Cassino, espaço sede do grupo, no Balneário Cassino, cidade de Rio Grande/RS.

\section{A produção de espetáculos e o protagonismo artístico}

Um dos eixos fundamentais que se articula pelo binômio educação-cultura está orientado para a formação de público, o qual se beneficia com a apresentação dos espetáculos que o grupo desenvolve junto ao projeto Bailar. Além disso, é interessante ressaltar também a grande importância que o projeto tem para a formação docente dos alunos de graduação, através do planejamento e da atuação em aulas de dança para a maturidade, participação nas montagens de espetáculos e os respectivos processos de criação e preparação corporal, interligando ações de ensino e pesquisa através da extensão.

Com relação às apresentações, concordamos com Strazzacappa (2012, p.90) que diz serem "parte importante da formação em dança, porém como resultado de todo um processo que desemboca num espetáculo". Todos os aspectos, desde a seleção de conteúdos até os modos como estes são encaminhados, surgem de um grande aprendizado em dança que são reconhecidos no trabalho realizado pelo grupo.

A dança, como área de conhecimento autônoma, vem ampliando seu espaço e lutando pelo devido reconhecimento de seu valor, principalmente na área acadêmica. Os cursos superiores de dança, além de auxiliarem na formação técnica em dança, ou seja, na formação do bailarino, propiciam a formação do criador, do pesquisador e do professor. Isso tem possibilitado uma reflexão muito maior a respeito do papel da dança na sociedade e diversificado 0 campo de atuação dos profissionais da área. (STRAZZACAPPA, 2012, p.91).

CASTRO, Daniela Llopart; HOFFMANN, Carmen Anita; SANTOS, Eleonora Campos da Motta. Baila Cassino Grupo de Dança e Projeto de Extensão Bailar: Núcleo de Dança na Maturidade como proposta de desenvolvimento e produção artístico-cultural. Revista da FUNDARTE, Montenegro, p.33-52, ano 19, no 37, Janeiro/Março.

Disponível em: http://.seer.fundarte.rs.gov.br/index.php/RevistadaFundarte/index> 30 de março de 2019. 


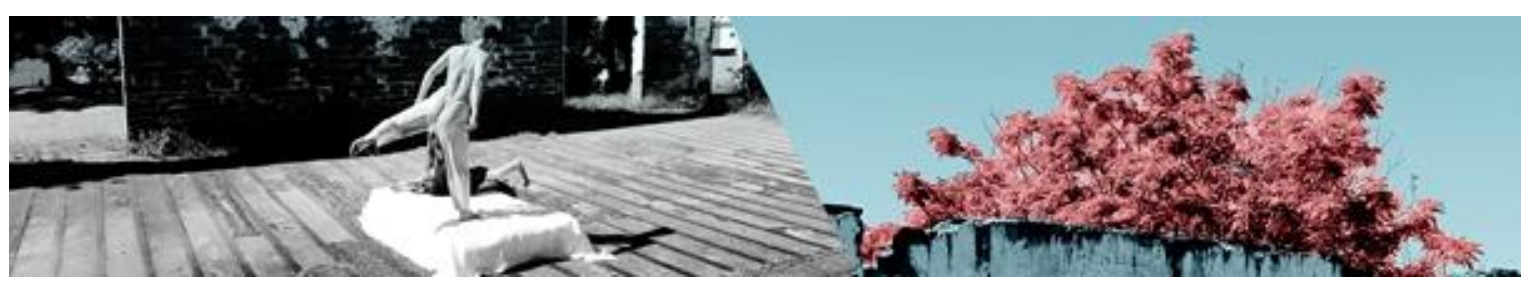

A seguir serão referendados os espetáculos que foram apresentados ao longo de uma década, como resultado de muito estudo e envolvimento do Grupo, dos acadêmicos, da coordenação, dos colaboradores e da apreciação do público sempre presente (Figura 4).

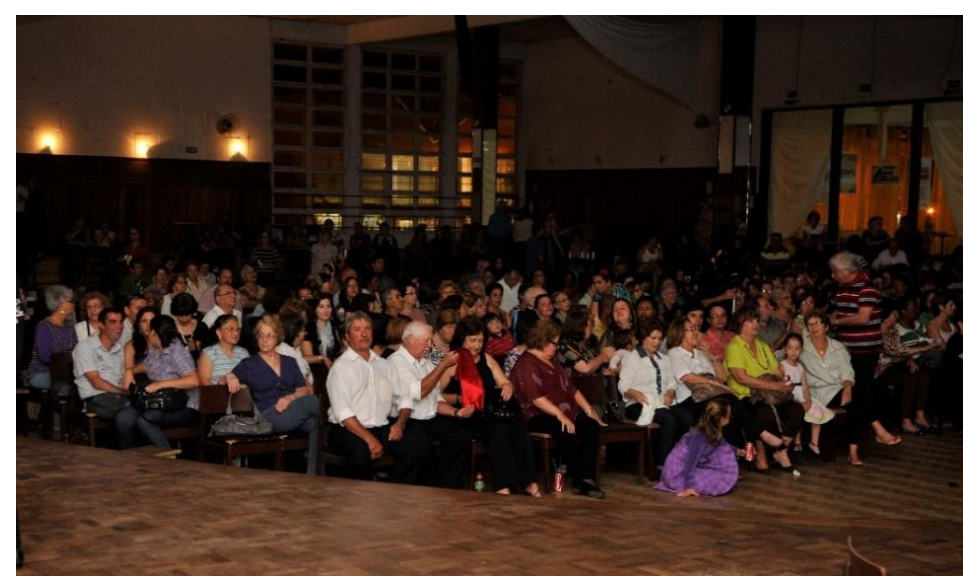

Figura 4: Plateia se organizando para assistir espetáculo do grupo, 2011. Foto: Leda Acosta

O primeiro deles foi Ritmos da Vida, que estreou em novembro de 2008 (Figura 5), com uma segunda apresentação em abril de 2009 na Festa do Mar, ambos na cidade de Rio Grande. Com nove bailarinas da maturidade, duas professoras, cinco crianças e um bailarino convidado, a obra se estruturou a partir de um texto construído especialmente para o espetáculo, retratando as diferentes fases da vida de mulheres que viveram ao longo do século XX. De acordo com Castro et al. (2016, p.90):

Foi uma proposta ousada através da qual as bailarinas se permitiram entrar em cena, realizando algo nunca feito por elas antes: participar de uma obra artística de dança. O espetáculo foi construído a partir das histórias de vidas das integrantes, criando uma única que unia todas as outras.

CASTRO, Daniela Llopart; HOFFMANN, Carmen Anita; SANTOS, Eleonora Campos da Motta. Baila Cassino Grupo de Dança e Projeto de Extensão Bailar: Núcleo de Dança na Maturidade como proposta de desenvolvimento e produção artístico-cultural. Revista da FUNDARTE, Montenegro, p.33-52, ano 19, no 37, Janeiro/Março.

Disponível em: http://.seer.fundarte.rs.gov.br/index.php/RevistadaFundarte/index> 30 de março de 2019. 

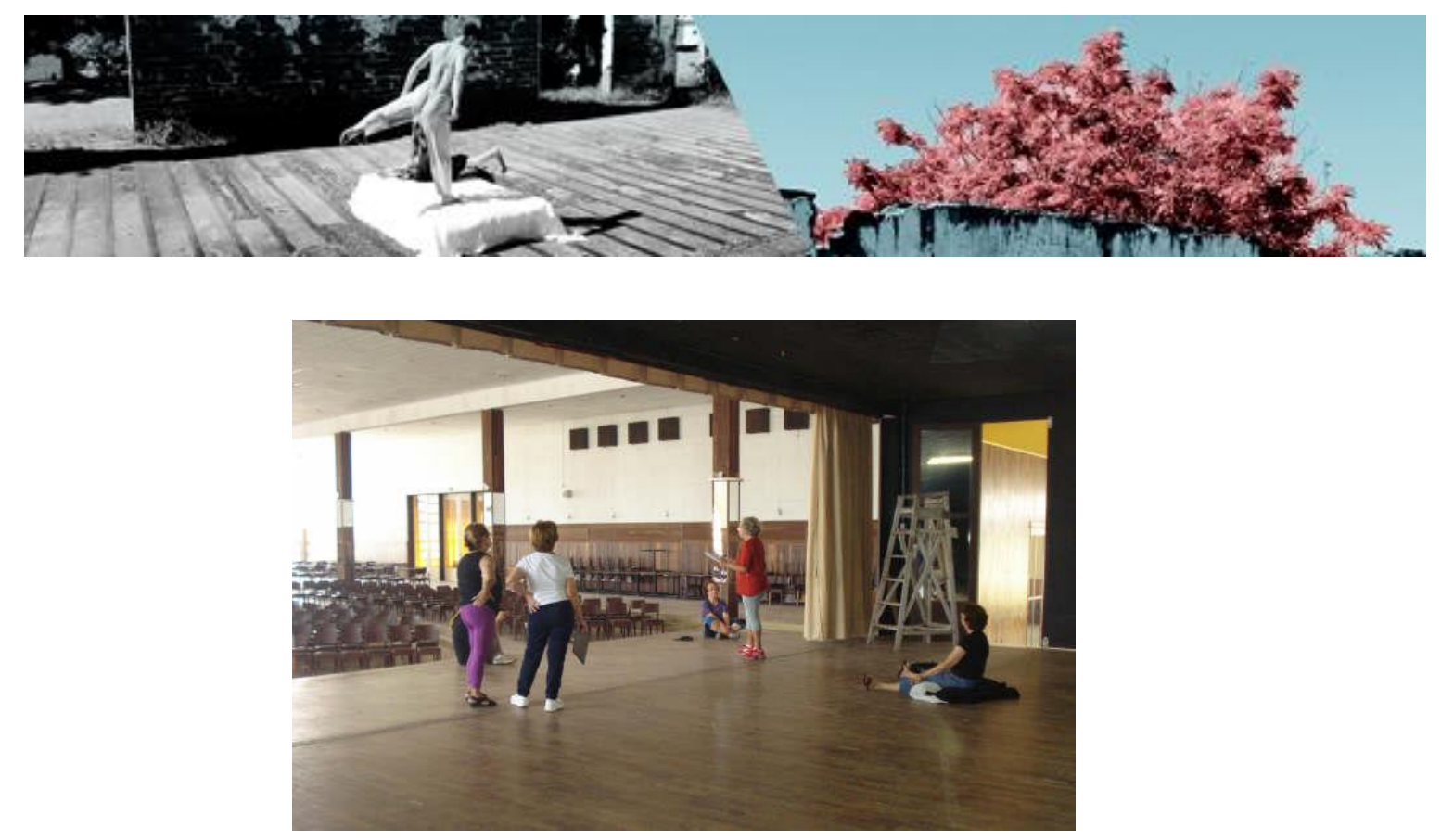

Figura 5: Ensaio e montagem de palco para o espetáculo Ritmos da Vida, 2008. Foto: Acervo do Baila Cassino

Salão Paraíso estreou em 2010 e, através do Prêmio Inezita Barroso, oferecido pelo Ministério da Cultura, circulou com a Turnê Salão Paraíso por cinco cidades no primeiro semestre de 2011 (Figura 6): Arroio Grande, Jaguarão, São José do Norte, Santa Vitória do Palmar e Porto Alegre, além de ter sido apresentado também na Festa do Mar em Rio Grande. "Esta circulação por diferentes cidades gaúchas atribuiu segurança ao trabalho que vinha sendo desenvolvido, possibilitando às integrantes vivências no universo e na rotina da arte que muitas não conheciam" (CASTRO, et al., 2016).

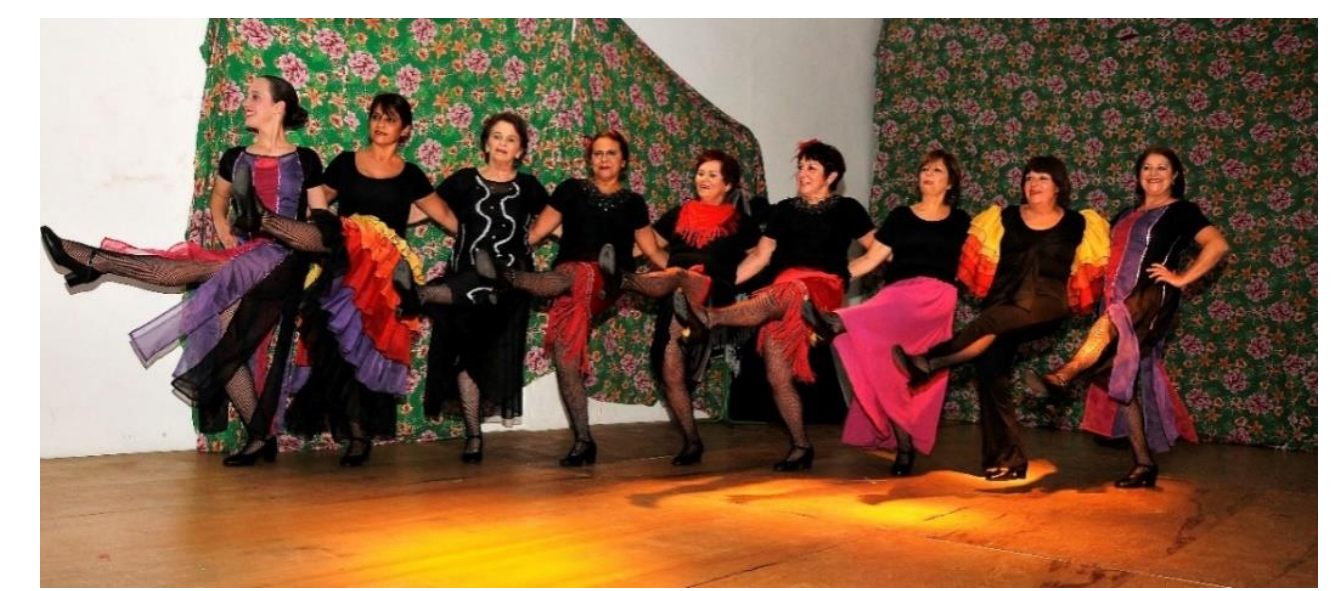

Figura 6: Cena do espetáculo Salão Paraíso em Porto Alegre, 2011. Foto: Leda Acosta

O espetáculo foi baseado na história da cidade de Rio Grande no início do

CASTRO, Daniela Llopart; HOFFMANN, Carmen Anita; SANTOS, Eleonora Campos da Motta. Baila Cassino Grupo de Dança e Projeto de Extensão Bailar: Núcleo de Dança na Maturidade como proposta de desenvolvimento e produção artístico-cultural. Revista da FUNDARTE, Montenegro, p.33-52, ano 19, no 37, Janeiro/Março.

Disponível em: http://.seer.fundarte.rs.gov.br/index.php/RevistadaFundarte/index> 30 de março de 2019. 


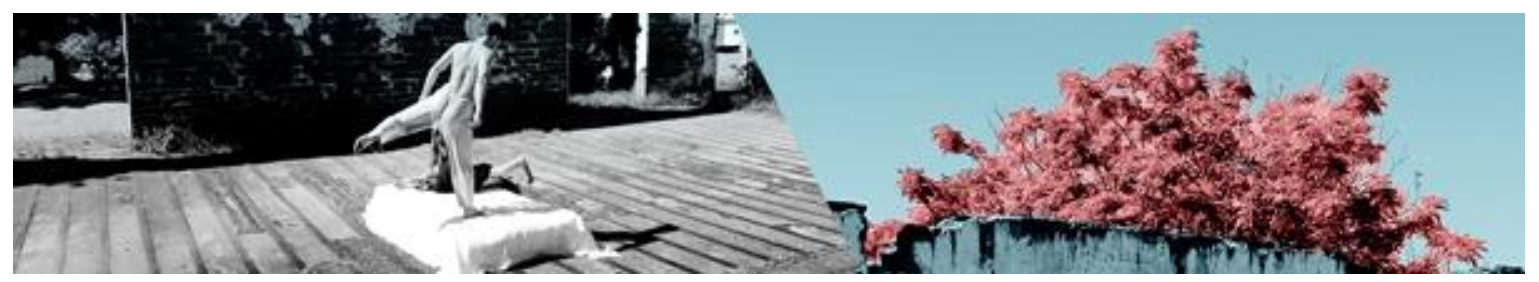

século XX, uma casa de shows que promovia concertos musicais, apresentações de companhias de variedades, reuniões dançantes e movimentados bailes de máscaras. Neste cenário se desenrolaram as coreografias dançadas e interpretadas pelas bailarinas do grupo. Fez-se uso da literatura existente e da memória de pessoas locais, trazendo à tona aspectos do cotidiano da cidade em determinada época, que foram ressignificados pelas bailarinas, acompanhando uma releitura histórica do município mais antigo do Rio Grande do Sul.

Mosaico estreou em novembro de 2011 em única apresentação (Figura 7). Teve como objetivo retratar o foco principal do grupo desde sua formação: dançar. Este espetáculo mostrou um pouco dos caminhos percorridos durante os cinco anos de existência do grupo, na busca da expressividade e do autoconhecimento relacionados à dança. Conforme Castro et al. (2016, p. 92), no espetáculo Mosaico:

...relatamos a história do Baila Cassino de maneira cênica, utilizando-se de um trabalho dramatúrgico de mise em scène, que já aparecia como importante recurso para o grupo, associado ao uso de falas/diálogos teatrais. A pantomima e os textos foram criados especialmente para o espetáculo e permitiram, em determinados momentos, que as bailarinas declamassem e interpretassem situações sobre si mesmas.

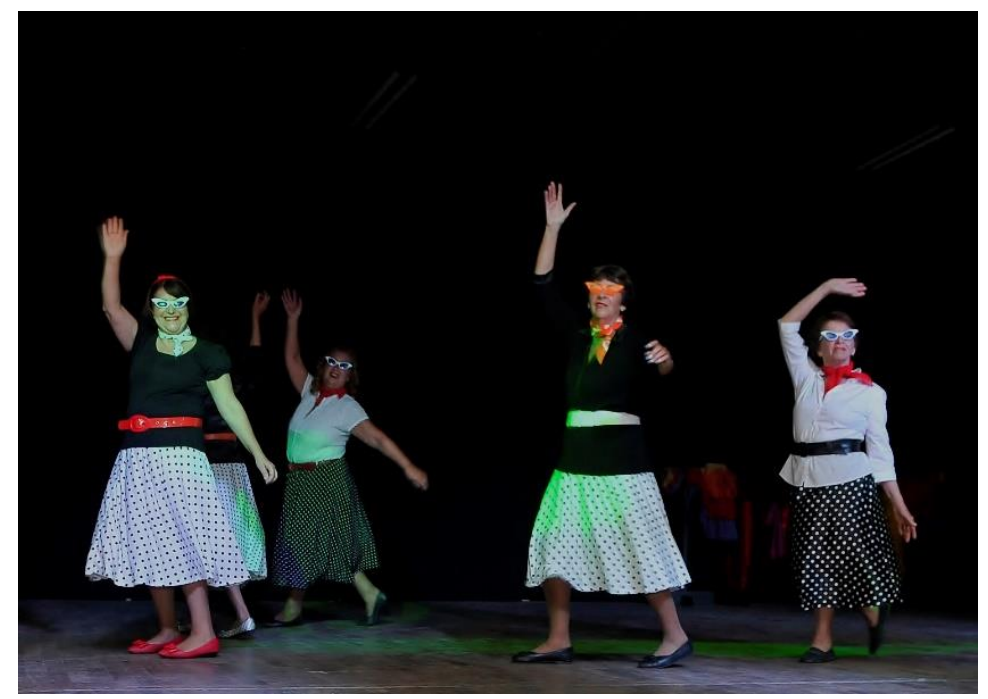

Figura 7: Cena do espetáculo Mosaico, 2011. Foto: Leda Acosta

O espetáculo Mamma Mia! (Figura 8) iniciou um novo ciclo para o grupo

CASTRO, Daniela Llopart; HOFFMANN, Carmen Anita; SANTOS, Eleonora Campos da Motta. Baila Cassino Grupo de Dança e Projeto de Extensão Bailar: Núcleo de Dança na Maturidade como proposta de desenvolvimento e produção artístico-cultural. Revista da FUNDARTE, Montenegro, p.33-52, ano 19, no 37, Janeiro/Março.

Disponível em: http://.seer.fundarte.rs.gov.br/index.php/RevistadaFundarte/index> 30 de março de 2019. 


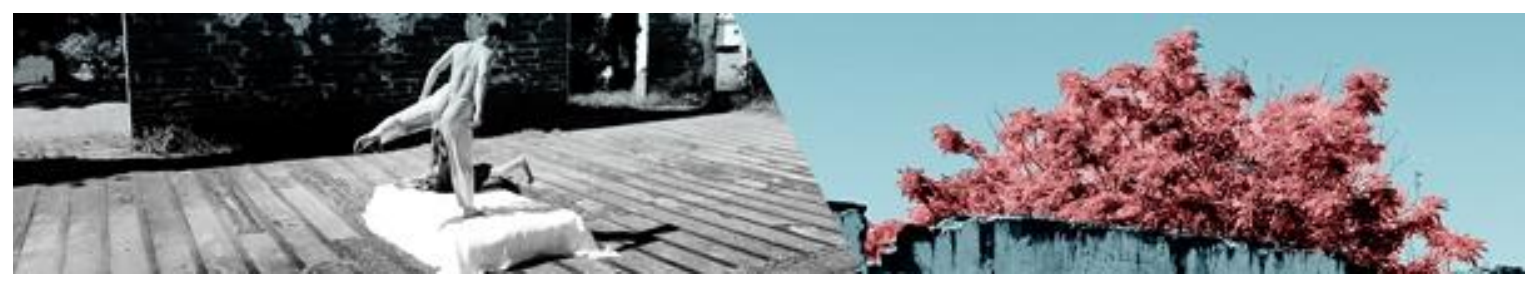

Baila Cassino. A partir deste ano o grupo passou a integrar o projeto de extensão Bailar, da Universidade de Pelotas e, com isso, foi desenvolvendo uma relação intergeracional mais intensa, através da circulação dos bolsistas, monitores e público universitário em geral nos eventos realizados pelo Baila Cassino. A obra estreou em novembro de 2012 e contou com mais três apresentações completas: na programação de verão da SAC em janeiro de 2013, na Festa do Mar em abril e no IF-Sul na cidade de Pelotas em maio do mesmo ano. A construção do espetáculo foi inspirada no filme Mamma Mia!, dirigido por Phyllida Lloyd, e narrava uma história sobre amor e amizade de uma mulher determinada e sonhadora que vivia com sua filha numa pequena ilha grega. Às vésperas de seu casamento a jovem decide buscar a identidade de seu pai entre os três amores de sua mãe na juventude. Com músicas do grupo sueco ABBA, as apresentações foram muito bem recebidas pelo público em geral, o que repercutiu positivamente para o envolvimento do Baila Cassino com a proposta do Projeto Bailar.

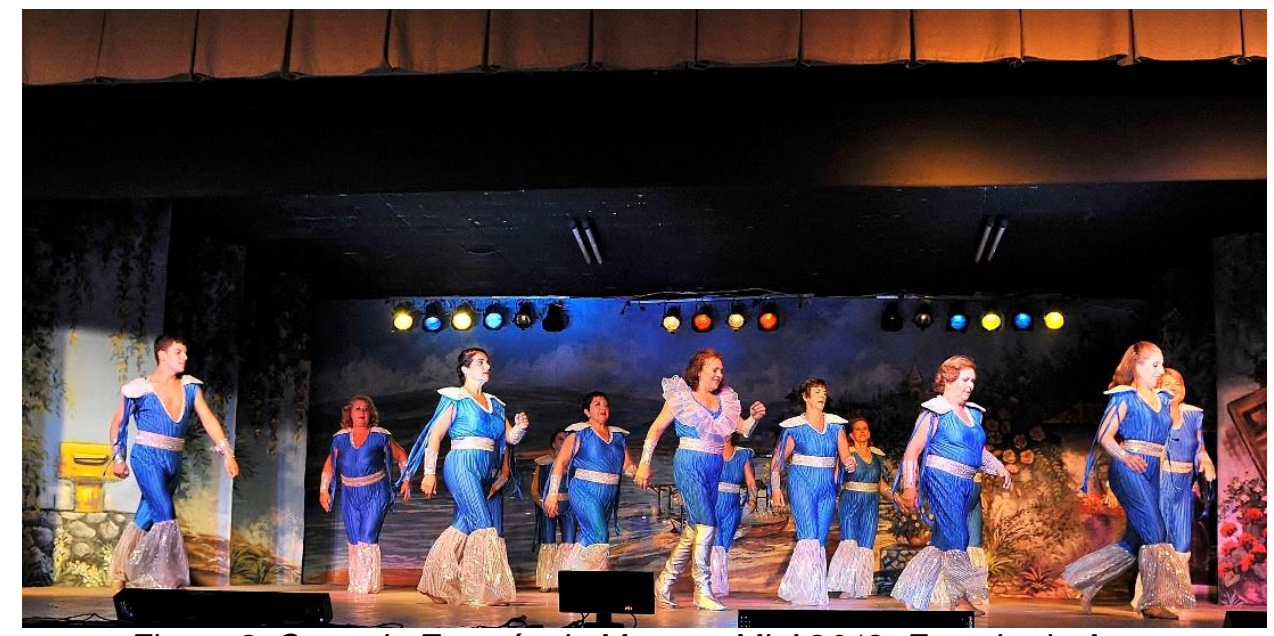

Figura 8: Cena do Espetáculo Mamma Mia! 2012. Foto: Leda Acosta

O espetáculo Olé! estreou em fevereiro de 2014 e contou ao todo com onze reapresentações, dentre elas uma em Pelotas/RS e duas na cidade de Montevidéu/Uruguai. Segundo Castro e Gonçalves (2014), entre sapateios, leques, balanço das saias, movimentos das mãos e uma expressão forte é que se destacaram as mulheres de 55 a 75 anos que participaram do Espetáculo Olé!

CASTRO, Daniela Llopart; HOFFMANN, Carmen Anita; SANTOS, Eleonora Campos da Motta. Baila Cassino Grupo de Dança e Projeto de Extensão Bailar: Núcleo de Dança na Maturidade como proposta de desenvolvimento e produção artístico-cultural. Revista da FUNDARTE, Montenegro, p.33-52, ano 19, n 37, Janeiro/Março.

Disponível em: http://.seer.fundarte.rs.gov.br/index.php/RevistadaFundarte/index> 30 de março de 2019. 


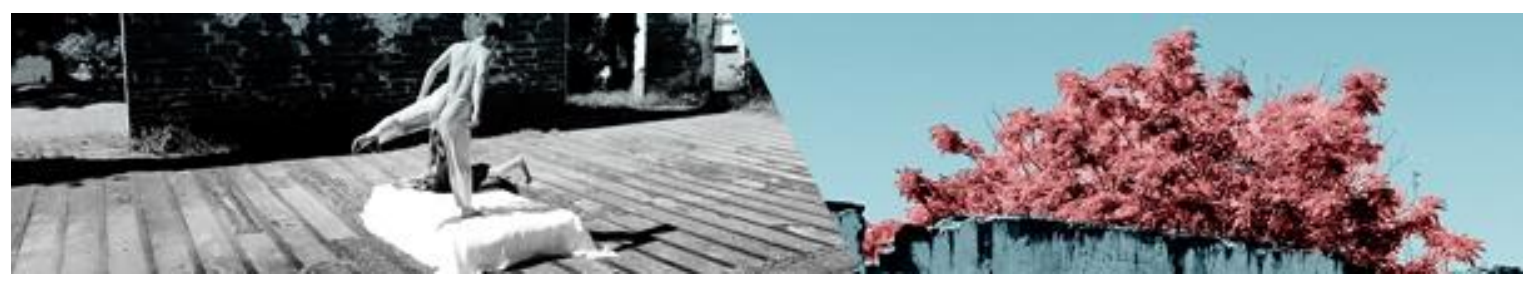

Baseado na cultura hispânica, a obra trouxe ao palco a ideia do sarau flamenco, utilizando-se de músicas e figurinos da região (Figura 9). A composição coreográfica partiu da técnica de dança livre, aproveitando o folclore de projeção para as propostas de movimento apresentadas, dessa forma, algumas coreografias apresentaram a leveza e ao mesmo tempo a força do povo cigano que se originou na Espanha. Com este trabalho, foi levado ao palco o diálogo entre as linguagens da dança, música, teatro e artesanato difundidos em sua composição. Para Castro et al. (2016, p.94):

Contrastando com o espetáculo anterior, esta obra não procurava narrar, de forma linear, uma história, mas sim propunha composições coreográficas diferenciadas que se uniam em torno de um mesmo tema. A contribuição dos acadêmicos se deu por meio da preparação corporal e cênica desenvolvidas com o grupo, permitindo que as bailarinas fossem para cena mais seguras, demonstrando bastante firmeza ao encarar os papéis que lhes foram propostos.

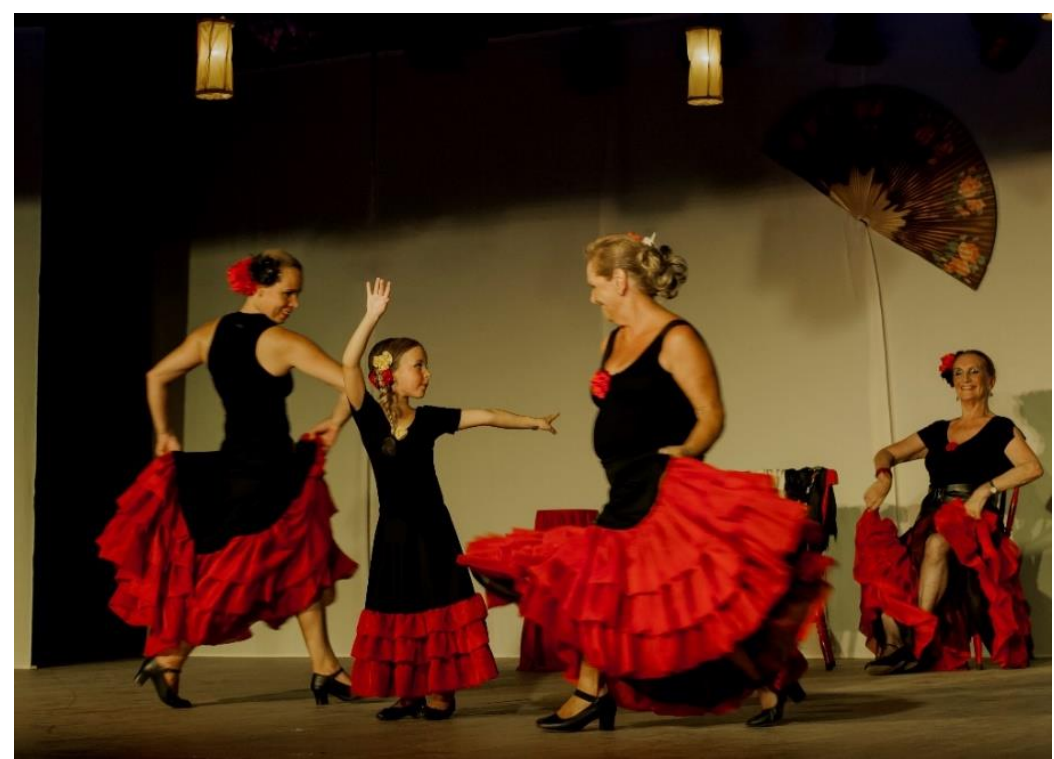

Figura 9: Cena do espetáculo OLÉ! 2014. Foto: Leda Acosta

O espetáculo mais recente do grupo foi Apenas Mulher... (Figura 10), que estreou em outubro de 2015 e foi apresentado diversas vezes, inclusive nas cidades de Pelotas, Santa Maria, Belo Horizonte e Montevidéu. Mostrando um amadurecimento enquanto trabalho coreográfico, esta obra foi construída com base na dança contemporânea, utilizando-se de improvisos, pesquisas de

CASTRO, Daniela Llopart; HOFFMANN, Carmen Anita; SANTOS, Eleonora Campos da Motta. Baila Cassino Grupo de Dança e Projeto de Extensão Bailar: Núcleo de Dança na Maturidade como proposta de desenvolvimento e produção artístico-cultural. Revista da FUNDARTE, Montenegro, p.33-52, ano 19, n 37, Janeiro/Março.

Disponível em: http://.seer.fundarte.rs.gov.br/index.php/RevistadaFundarte/index> 30 de março de 2019. 


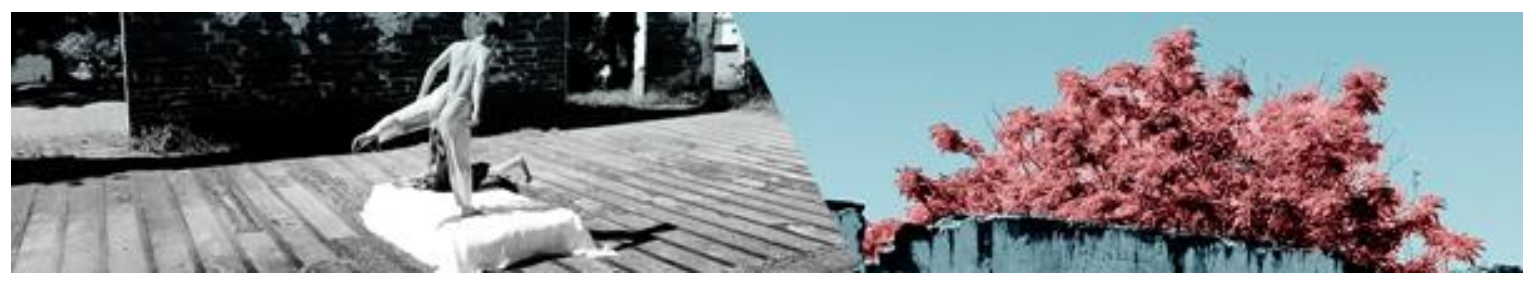

movimento e criação colaborativa. Concordando com Castro et al. (2016, p.96), foi "uma obra que levou ao palco um retrato da mulher brasileira, por meio da seleção de músicas cantadas por grandes intérpretes nacionais e a exploração de movimentações das dançarinas referenciadas na dança contemporânea".

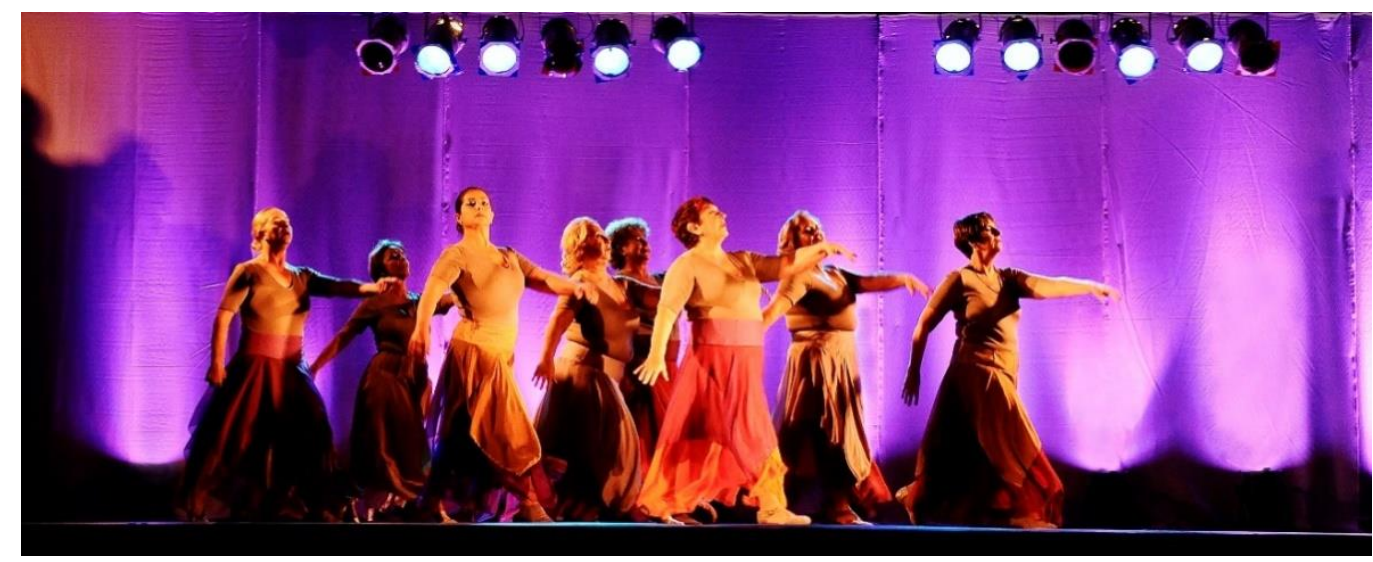

Figura 10: Cena do Espetáculo Apenas Mulher, 2015. Foto: Leda Acosta

A atuação dos monitores, bolsistas de extensão e egressos se monstra presente na forma de organização desse trabalho, construído de maneira bastante coletiva e com provocações teóricas intensas. A cada nova obra o grupo Baila Cassino se envolve mais com o projeto Bailar, compreendendo a riqueza das trocas proporcionadas por esta relação.

\section{0 anos de Baila Cassino e o efetivo exercício da extensão universitária}

No ano de comemoração de seus 10 anos de existência, o Grupo Baila Cassino tem promovido diversas ações, a primeira delas foi a Festa da Década: Mulheres na SAC (Figura 11), que iniciou os festejos de aniversário. As bailarinas apresentaram uma performance fazendo referência aos seis espetáculos realizados pelo grupo, além de receberem grupos de dança convidados.

CASTRO, Daniela Llopart; HOFFMANN, Carmen Anita; SANTOS, Eleonora Campos da Motta. Baila Cassino Grupo de Dança e Projeto de Extensão Bailar: Núcleo de Dança na Maturidade como proposta de desenvolvimento e produção artístico-cultural. Revista da FUNDARTE, Montenegro, p.33-52, ano 19, n 37, Janeiro/Março.

Disponível em: http://.seer.fundarte.rs.gov.br/index.php/RevistadaFundarte/index> 30 de março de 2019. 

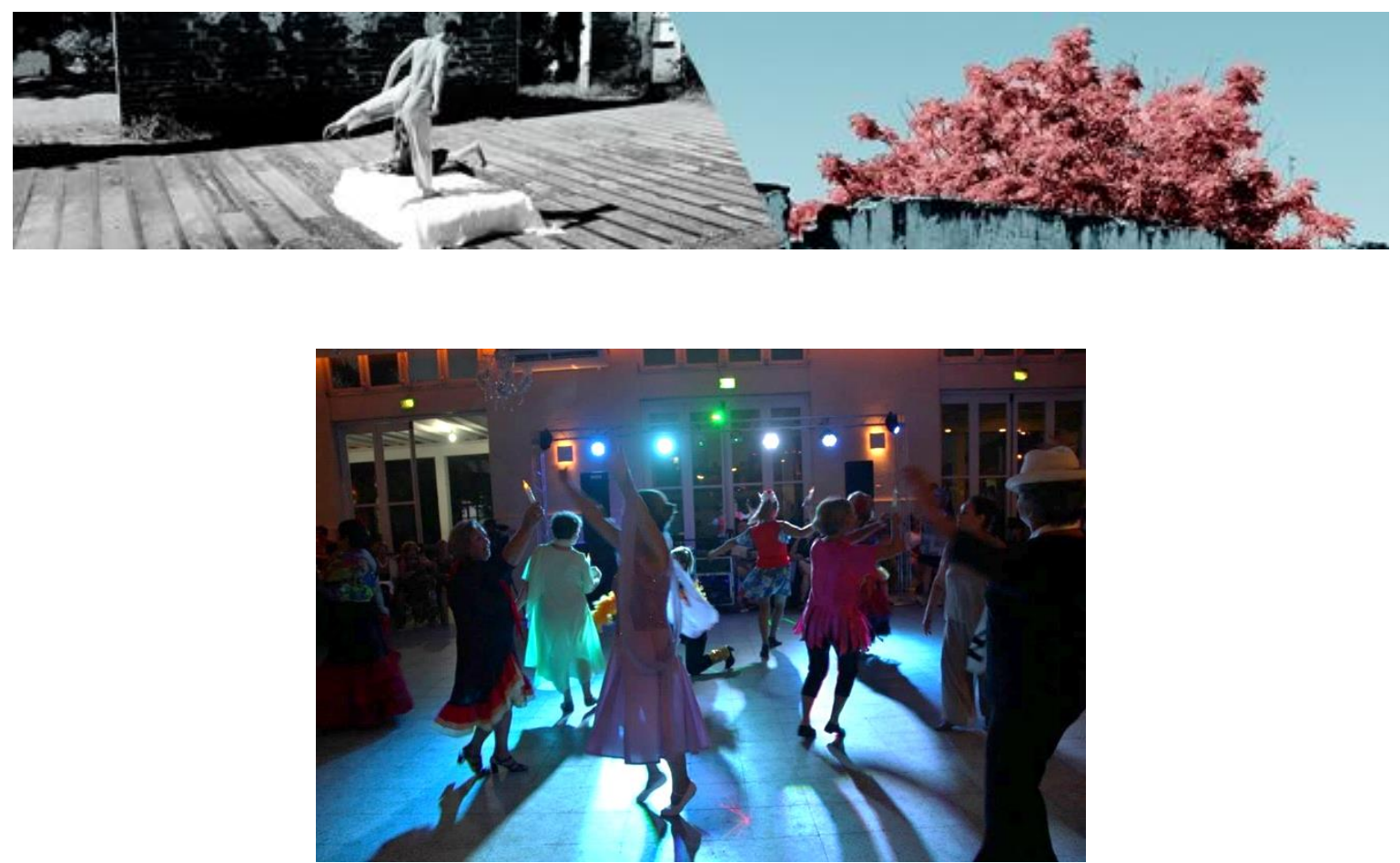

Figura 11: Festa da Década, Sociedade Amigos do Cassino, janeiro 2017. Foto: Paula Liaroma

Na sequência, promoveram um brechó que subsidiou a realização do Sarau dos 10 anos (Figura 12). Este aconteceu num casarão do início do século $X X$, na Avenida Rio Grande, no balneário Cassino, local de encontro da burguesia da época. A temática fez referência aos anos 20, com figurinos e decoração que remetia ao período de ostentação da vila balnear. No sarau houve diversas apresentações de artistas convidados e o grupo anfitrião apresentou a performance intitulada "Chá das Cinco".

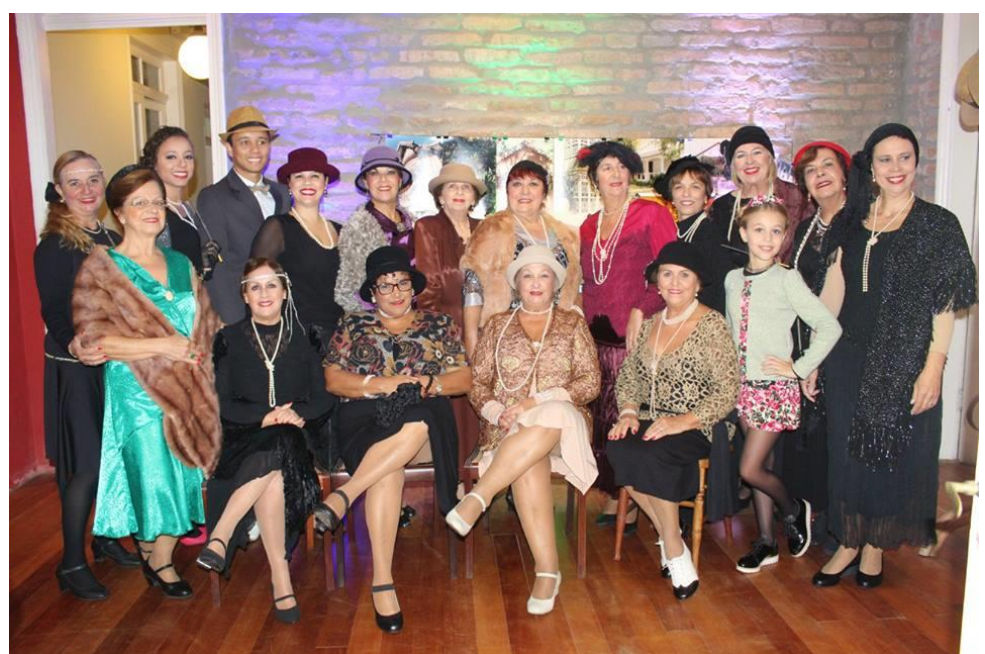

Figura 12: Noite do Sarau Década de 20, 2017. Foto: Acervo do Baila Cassino

Durante as comemorações de aniversário, a participação da comunidade acadêmica aparece de diferentes formas. Bolsistas e monitores do projeto Bailar CASTRO, Daniela Llopart; HOFFMANN, Carmen Anita; SANTOS, Eleonora Campos da Motta. Baila Cassino Grupo de Dança e Projeto de Extensão Bailar: Núcleo de Dança na Maturidade como proposta de desenvolvimento e produção artístico-cultural. Revista da FUNDARTE, Montenegro, p.33-52, ano 19, no 37, Janeiro/Março.

Disponível em: http://.seer.fundarte.rs.gov.br/index.php/RevistadaFundarte/index> 30 de março de 2019. 


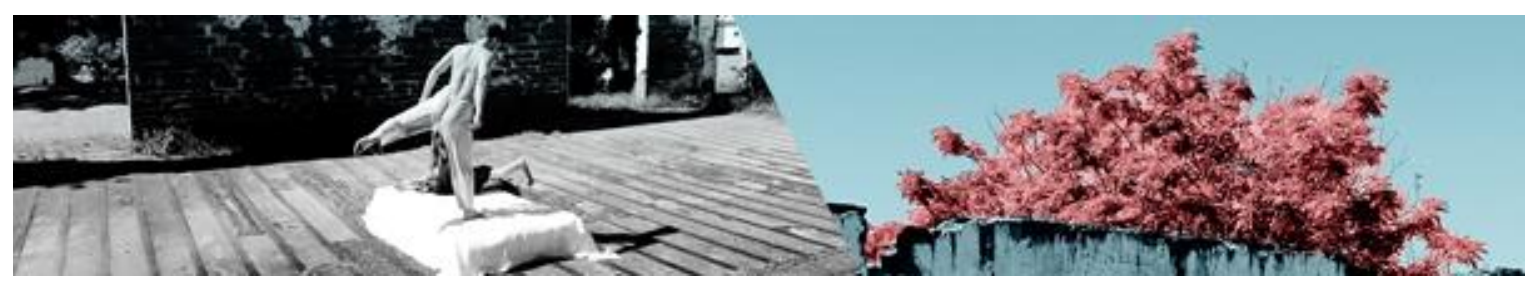

atuam em diversas frentes para colaborar com a organização dos eventos, desde a confecção de cartazes e programas, até as funções de ensaiadores, técnicos de som, fotógrafos, etc. Antigos alunos, atualmente licenciados em dança, trabalham enquanto professores do grupo, e também trazem suas produções artísticas para interagir com as propostas do Baila Cassino. Professores do curso de dança da UFPel contribuem com oficinas e teorizações relacionadas à dança na maturidade, proporcionando a circulação do grupo por diferentes cidades onde se torna possível mostrar sua arte; e o público universitário em geral frui dança produzida com corpos maduros, compreendendo a importância desse novo olhar para a mudança de paradigma em relação ao artista mais velho.

Pensar nesta relação nos faz compreender que ações já existentes na comunidade, a exemplo do grupo Baila Cassino, permitem fomentar experiências com a universidade ao mesmo tempo em que a opção pela parceria com esta instituição, através do projeto Bailar, potencializou a ação da comunidade. Desta forma, concordamos com Castro (2004) ao afirmar que a extensão pressupõe a presença de um outro, além do aluno e do professor, permitindo uma ampliação da experiência onde narrador e ouvinte se misturam e se revezam nos papéis. Ao construir a experiência numa relação emancipatória, outros narradores e outros ouvintes podem surgir a partir daí. O conhecimento assim produzido é um conhecimento que circula, podendo ser testado e, dessa forma, agregar a ele novos valores. A difusão do conhecimento, assim, não é uma mera repetição, mas serve, com base na narrativa, para caminhar de outro modo.

Em paralelo às comemorações programadas, o Grupo recebeu manifestações de reconhecimento da comunidade. Uma destas foi o prêmio junto ao Projeto Bailar: Núcleo de dança na Maturidade, a Medalha da 54ํㅡㄴ Legislatura do Parlamento Gaúcho, em homenagem ao trabalho realizado. As bailarinas do grupo, ao final da cerimônia, dançaram uma pequena parte de seu último espetáculo Apenas Mulher (Figura 13), encantando o público presente.

CASTRO, Daniela Llopart; HOFFMANN, Carmen Anita; SANTOS, Eleonora Campos da Motta. Baila Cassino Grupo de Dança e Projeto de Extensão Bailar: Núcleo de Dança na Maturidade como proposta de desenvolvimento e produção artístico-cultural. Revista da FUNDARTE, Montenegro, p.33-52, ano 19, no 37, Janeiro/Março.

Disponível em: http://.seer.fundarte.rs.gov.br/index.php/RevistadaFundarte/index> 30 de março de 2019. 

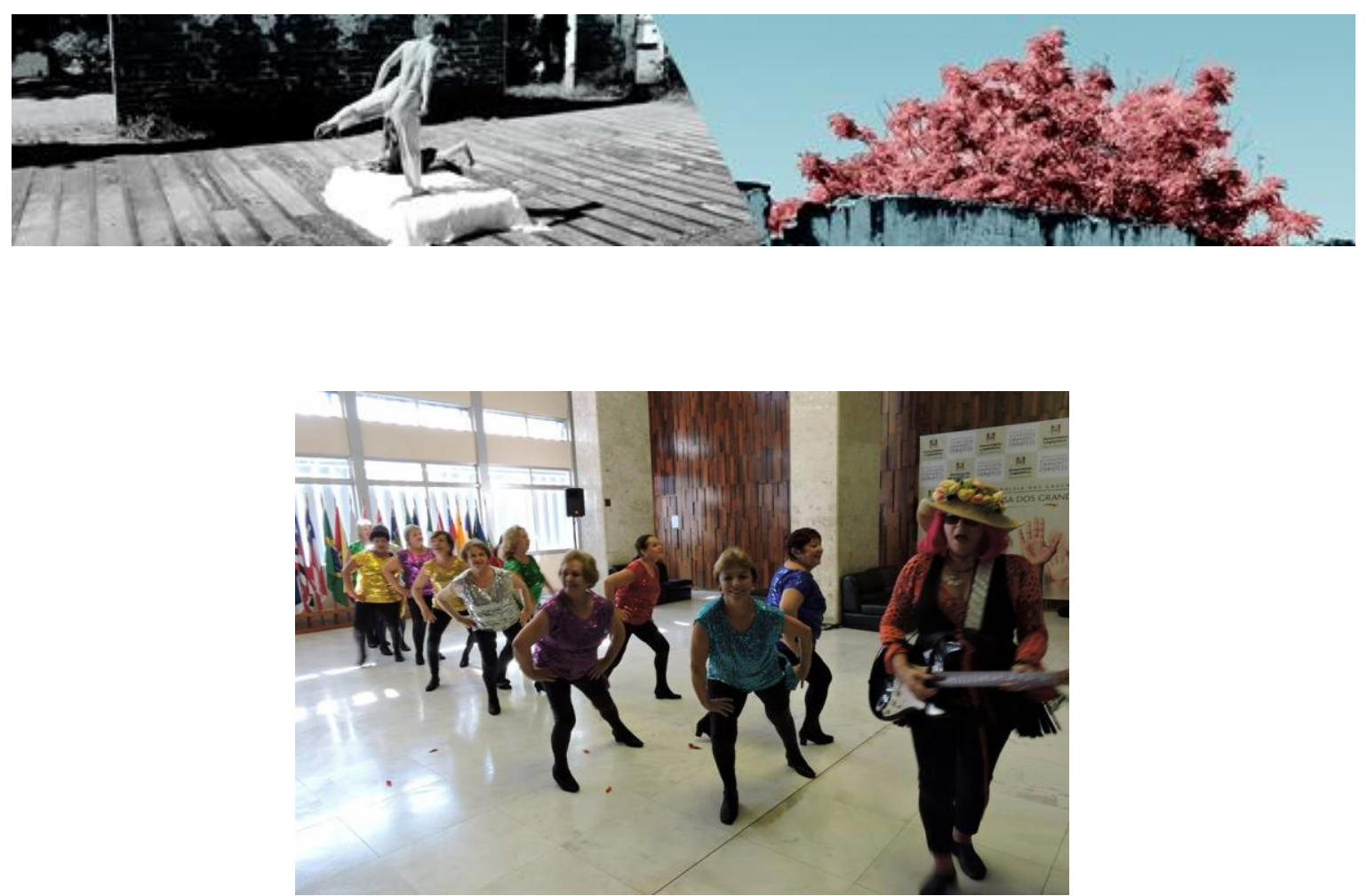

Figura 13: Apresentação na Assembleia Legislativa do Estado do Rio Grande do Sul 2017. Foto: Acervo do Baila Cassino

Com sensibilidade e sabedoria, a escolha do Baila Cassino e do Projeto Bailar para obter esta medalha, mostra a percepção sobre os pilares artísticos e sociais do trabalho que vem sendo desenvolvido ao longo destes dez anos por todas as mulheres que estão ou já passaram pela experiência junto ao grupo. Muitas foram às atividades - aulas, cursos, seminários, performances, espetáculos, publicações acadêmicas e bibliográficas, reuniões, viagens, eventos diversos - que contribuíram com o crescimento e amadurecimento da proposta até chegar ao modelo atual. $\mathrm{O}$ reconhecimento deste trabalho estimula sua continuidade e salienta sua importância no seio da comunidade gaúcha, fortalecendo a parceria do Grupo Baila Cassino com a UFPel, através de sua relação junto ao projeto de Extensão Bailar: Núcleo de Dança na Maturidade.

Através de exemplos como esse, seguimos trabalhando na estruturação de uma universidade aberta e inclusiva, pactuando com Rodrigues (2005-2006, p.85) quando diz que:

A Universidade somente poderá ter sua extensão institucionalizada se os seus muros deixarem de existir e a comunidade tiver livre trânsito no seu interior, influenciando o ambiente acadêmico e sendo por ele influenciado, destruindo, assim, a concepção meramente assistencialista de extensão.

CASTRO, Daniela Llopart; HOFFMANN, Carmen Anita; SANTOS, Eleonora Campos da Motta. Baila Cassino Grupo de Dança e Projeto de Extensão Bailar: Núcleo de Dança na Maturidade como proposta de desenvolvimento e produção artístico-cultural. Revista da FUNDARTE, Montenegro, p.33-52, ano 19, no 37, Janeiro/Março.

Disponível em: http://.seer.fundarte.rs.gov.br/index.php/RevistadaFundarte/index> 30 de março de 2019. 


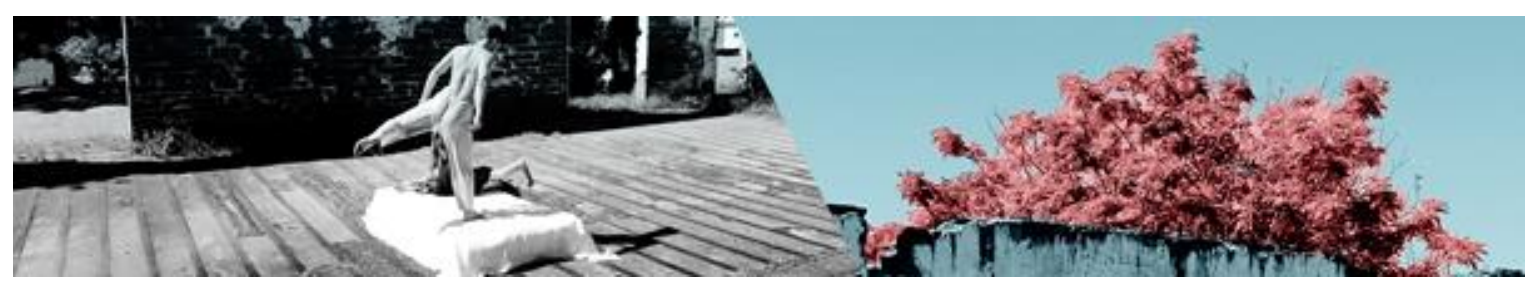

O trabalho desenvolvido pelo projeto Bailar tem permitido observar que a terceira idade pode se caracterizar como a época em que as pessoas se redescobrem, encontram velhos interesses e motivações, estabelecem novos relacionamentos e projetos, continuando a utilizar o processo criativo. As ações que estão sendo propostas são importantes para os idosos se manterem ativos e voltados para o mundo externo, para sentirem prazer em acompanhar os interesses do mundo, para se projetarem no futuro, criarem novas metas, reverem experiências do passado e, também, para poderem se encaminhar com maior maturidade para o futuro.

\section{Considerações Finais}

A apresentação deste texto buscou reafirmar a importância da atuação extensionista que a Universidade Federal de Pelotas tem através do projeto Bailar: Núcleo de Dança na Maturidade junto ao trabalho desenvolvido pelo Grupo de Dança Baila Cassino, especialmente por reconhecer a necessidade de implementar ações disparadoras e orientadoras para grupos de maturidade.

A vivência das participantes do grupo pode não corresponder à realidade de toda a população de terceira idade, mas demonstra que esta fase da vida pode ser marcada por alegrias, satisfações e realizações. As bailarinas são estimuladas a continuarem tendo objetivos, crescerem pelas trocas de experiências e a desenvolverem a criatividade.

Algumas ações promovidas pelo grupo têm reverberado muitos aspectos positivos para a região, como a realização de espetáculos, oficinas e seminários que são pensados estrategicamente para a inserção da arte da dança na maturidade.

Para além da relação com a comunidade em geral, através das atividades mencionadas, apontamos a potencialidade do Projeto Bailar no que tange às ações acadêmicas e à importância do diálogo entre teoria e prática na construção dos saberes e das escolhas profissionais dos discentes da UFPel que com esta proposta extensionista se envolvem. Em outras palavras, consideramos oportuno destacar que a maioria dos monitores e bolsistas que atuaram/atuam no projeto, por essa via,

CASTRO, Daniela Llopart; HOFFMANN, Carmen Anita; SANTOS, Eleonora Campos da Motta. Baila Cassino Grupo de Dança e Projeto de Extensão Bailar: Núcleo de Dança na Maturidade como proposta de desenvolvimento e produção artístico-cultural. Revista da FUNDARTE, Montenegro, p.33-52, ano 19, no 37, Janeiro/Março.

Disponível em: http://.seer.fundarte.rs.gov.br/index.php/RevistadaFundarte/index> 30 de março de 2019. 


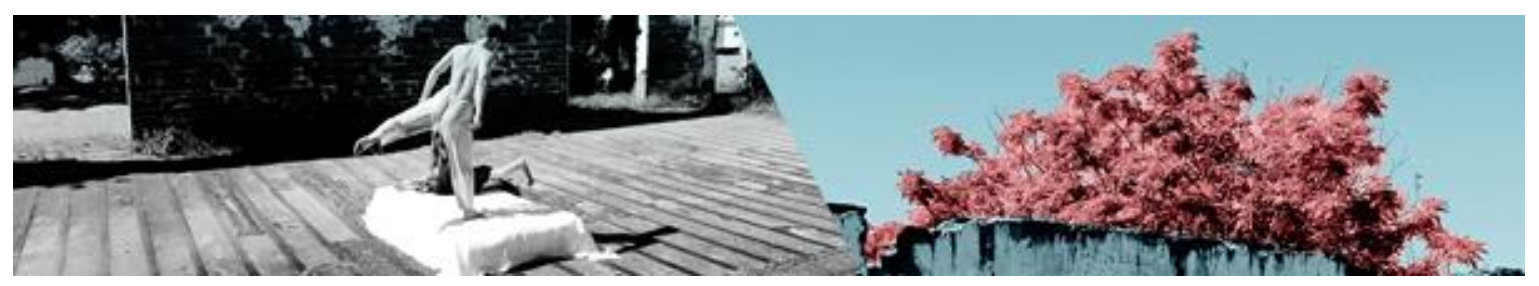

reconheceram o interesse e a oportunidade em atuar profissionalmente com 0 público da maturidade ou reafirmaram desejo pré-existente. Como exemplo podemos citar a produção de seus trabalhos de conclusão de curso tratando sobre o tema (ALMEIDA, 2014; SALDANHA, 2017; NEUTZLING, 2017) ${ }^{4}$, bem como sua atuação no mercado de trabalho através da prática docente em dança de salão, balé e dança contemporânea para e com o público maduro. A atual direção geral do Baila Cassino, é exercida, inclusive, por egressa do Curso de Dança-Licenciatura da UFPel que, enquanto discente da graduação, atuou como monitora voluntária e, posteriormente, como bolsista de extensão do Projeto Bailar por dois semestres. Além disso, a existência do projeto faz com que o assunto "Dança na Maturidade" seja bastante presente nas discussões em sala de aula, o que colabora para o interesse e incentiva a produção de trabalhos sobre essa temática, mesmo nos alunos que não atuam diretamente no Bailar (MARINHO, 2013; PEREIRA, 2014).

Assim, acreditando ainda mais na relevância de trabalhos comprometidos com a educação e a cultura, destacamos aqui a materialização do papel extensionista da universidade, que se constitui em um espaço multidisciplinar onde a dança é trabalhada através de uma proposta artística para adultos maduros e para formação complementar dos licenciandos, que vivenciam intensamente um trabalho com um público cada vez mais inserido no universo acadêmico.

Este projeto contribui para o reconhecimento institucional, articulando-se por meio de uma política de inclusão social, que é orientada pela valorização da diversidade cultural, e, além disso, oferece notável oportunidade para organizar e compartilhar o pensamento gerado pela reflexão sobre o que a produção artística na maturidade pode trazer de novo para a cena contemporânea da dança e o ensino da dança na universidade e na sociedade em geral.

\footnotetext{
${ }^{4}$ Estes TCCs estão disponíveis, em versão completa, pelo link http://wp.ufpel.edu.br/danca/graduacao/trabalhos-de-conclusao/.
}

CASTRO, Daniela Llopart; HOFFMANN, Carmen Anita; SANTOS, Eleonora Campos da Motta. Baila Cassino Grupo de Dança e Projeto de Extensão Bailar: Núcleo de Dança na Maturidade como proposta de desenvolvimento e produção artístico-cultural. Revista da FUNDARTE, Montenegro, p.33-52, ano 19, no 37, Janeiro/Março.

Disponível em: http://.seer.fundarte.rs.gov.br/index.php/RevistadaFundarte/index> 30 de março de 2019. 


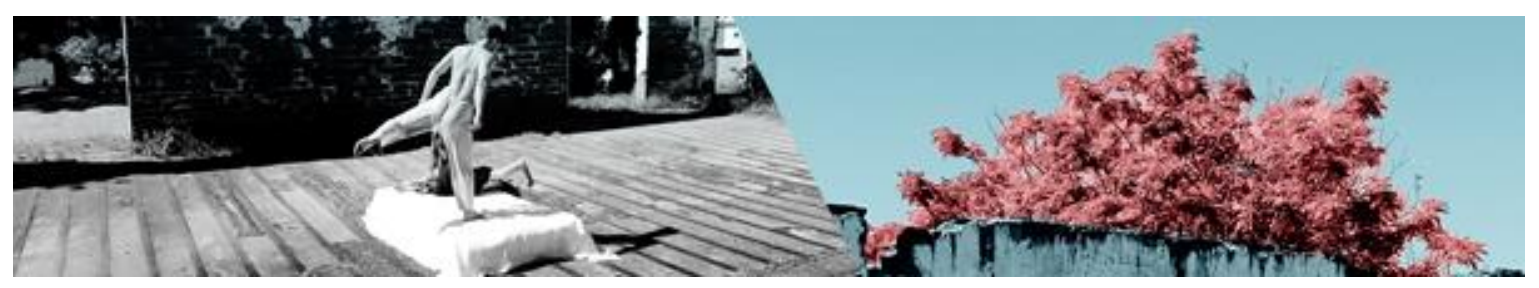

\section{Referências:}

ALMEIDA, Alex Sander Silveira. Entre o artístico e o terapêutico: um olhar sobre o Grupo Kiriann Teatro de Dança. 2014. 120 f. Trabalho de Conclusão de Curso (Graduação em Dança) - Centro de Artes, Universidade Federal de Pelotas, 2014.

CASTRO, Daniela Llopart. Corpos Dançantes na maturidade: compreendendo um universo diverso. In: III Seminário Internacional de Arte: corpo e experiência vivida, 3, 2016, Ibirité. Anais... Belo Horizonte: Alba Pedreira Vieira, Fernanda Abbatepietro Novaes, Isabel Cristina Vieira Coimbra Diniz (editoras), 2017. p. 38-44.

CASTRO, Daniela; GONÇALVES, Maiara; SAYÃO, Maria Eduarda; SAN MARTINS, Rebeca; SANTOS, Eleonora. A maturidade em cena: experiências com o espetáculo Apenas Mulher no Projeto Bailar. Paralelo 31. n.7, p.89-114, dez, 2016.

CASTRO, Daniela; GONÇALVES, Maiara. Espetáculo Olé e Projeto Bailar: una experiencia artística en la edad madura. 2da Bienal de Educación y Arte. Montevidéo, 2014.

CASTRO, Luciana Maria. A universidade, a extensão universitária e a produção de conhecimentos emancipadores. In: Reunião Anual da ANPED, 27, Caxambu, 2004. Anais... Caxambu: ANPED, 2004. Acesso em: 10 out 2017. Disponível em: <http://www.anped.org.br/reunioes/27/inicio.htm>

FIGUEIREDO, Adma Hamam (org.). Brasil: uma visão geográfica e ambiental do início do século XXI. Instituto Brasileiro de Geografia e Estatística (IBGE), 2016.

GARCÊS, Solange B. Billig, et.al. GIEEH - Grupo Interdisciplinar de Estudos do Envelhecimento Humano da UNICRUZ: Tecendo os fios entre o Envelhecimento e a Educação em uma Sociedade (Pós)Moderna. In: CAMARGO, Maria Aparecida Santana et.al. (orgs). Pesquisa na Universidade: mosaico de vivências acadêmicas. Santa Maria: Pallotti, 2012.

MARINHO, Thomas Porto. Dançando a Vida: um método de ensino para terceira idade., 2013. 55f. Trabalho de Conclusão de Curso - Centro de Artes, Universidade Federal de Pelotas, Pelotas, 2013.

NEUTZLING, Andrine Porciuncula. Dança na Maturidade: Caminhos que permeiam os propósitos dos professores/coordenadores e a produção artística. 2017. 102f. Trabalho de Conclusão de Curso - Centro de Artes, Universidade Federal de Pelotas, Pelotas, 2017.

PEREIRA, Josiane da Mota. Motivos da permanência das integrantes do grupo de danças da maturidade no espaço Laís Hallal, 2014. 87f. Trabalho de Conclusão de Curso - Centro de Artes, Universidade Federal de Pelotas, Pelotas, 2014. 


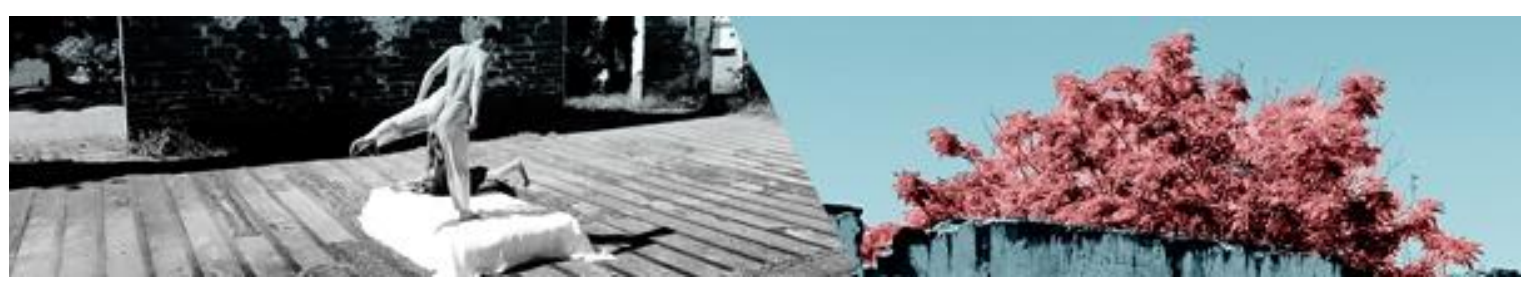

RODRIGUES, R. A extensão universitária como uma práxis. Em Extensão. Uberlândia. v.5, p. 84-88, 2005-2006.

STRAZZACAPPA, Márcia; MORANDI, Carla. Entre a Arte e a Docência. Campinas: Papirus, 2012.

VIEIRA, Marcílio. A memória gruda na pele ou a dança madura no corpo. Art Research Journal/Revista de Pesquisa em Arte. v.3, n.2, p.160-177, 2016. Acesso em: 22, mai, 2017.2 Disponível em: <https://periodicos.ufrn.br/artresearchjournal/article/view/9525/7812>

CASTRO, Daniela Llopart; HOFFMANN, Carmen Anita; SANTOS, Eleonora Campos da Motta. Baila Cassino Grupo de Dança e Projeto de Extensão Bailar: Núcleo de Dança na Maturidade como proposta de desenvolvimento e produção artístico-cultural. Revista da FUNDARTE, Montenegro, p.33-52, ano 19, no 37, Janeiro/Março.

Disponível em: http://.seer.fundarte.rs.gov.br/index.php/RevistadaFundarte/index> 30 de março de 2019. 